\title{
INCIDENCE OF MAIZE WEEVIL (Sitophilus zeamais Motsch) AND ITS ASSOCIATION WITH GREEN FUNGUS (Aspergillus flavus Link) IN MAIZE UNDER STORAGE AT CHITWAN AND SURKHET DISTRICTS OF NEPAL
}

\author{
K. Bhusal and D. Khanal* \\ Institute of Agriculture and Animal Science, Tribhuvan University, Nepal \\ *dipak@iaas.edu.np
}

\begin{abstract}
A survey of maize-growing areas of Surkhet and Chitwan, Nepal (April to May 2017) was conducted to know about the incidence, relationship and loss in stored maize due to Maize weevil (Sitophilus zeamais Motsch) and (Aspergillus flavus Link). Sixty households from each district were surveyed and the data was analyzed using SPSS and Microsoft Excel. Result revealed that there is severe infestation of maize weevil and green fungus in stored maize. $97.5 \%$ of stored samples had incidence of Aspergillus, whereas $96.7 \%$ samples had maize weevils. $15.7 \%$ of the farmers apply sun drying and removal of the $A$. falvus infested seed while remaining $84.3 \%$ of the farmers use no any measure of control. Results from Chi- Square test indicated significant relation $\left(\chi^{2}=122.10, \mathrm{P}<0.01\right)$ between incidence of weevil infestation and occurrence of green fungus in the study area. The Phi coefficient value (1.00) shows the perfect relationship exist between weevil and green fungus occurrence in the study areas. The overall annual damage by the A. flavus was $6.39 \%$. Therefore, it can be said that maize weevil is the major insect while $A$. flavus is major pathogen of maize grains at storage. The relationship between the occurrences of both pests was highly significant which indicated the positive relationship, i.e. the weevil plays an essential role in growth and spread of fungus.
\end{abstract}

Key words: Incidence, maize weevil, green fungus, storage, relationship

\section{INTRODUCTION}

Maize (Zea mays L.), belonging to the family Poaceae or Gramineae is ranking second in area cultivated and first in production and productivity in order of world grain production (FAO, 2013). It is popularly known as queen of cereals, because of very high yield potential than any other cereals (Singh, 2002). It occupies $26.12 \%$ of total cereal cultivated area and shares about $23.15 \%$ of the total cereal production in Nepal. Both in terms of area and production, maize ranks second after rice in Nepal. It is grown in 882395 ha of land with an average yield of $2.43 \mathrm{mt} / \mathrm{ha}$ (MoAD, 2014/15) which seems to be very low as compared to neighboring countries. The maize weevil (Sitophilus zeamais Motsch), known as the greater rice weevil, is a species of beetle in the family curculionidae. The maize weevils are small (2.5 $\mathrm{mm}$ to $4 \mathrm{~mm}$ length) brown black weevils with a long slender snout and four reddish brown spots on the wing covers (two spots on each wing cover). The head and thorax are nearly as long as the wing covers. In world, they are considered as a major pest of corn. Infestations not only cause significant economic losses but also result in elevated temperature and moisture conditions that lead to an accelerated growth of molds, including toxigenic species (Magan et al., 2003).

Aspergillus flavus Link is a saprobe, a pathogen and a producer of several mycotoxins that impact human and animal health (Masayuki and Gomi, 2010). It is an anamorphic genus consisting of about 250 recognized species. It is characterized by a distinctive spore-bearing structure, the aspergillum. It is cosmopolitan in distribution (Ramirez et al, 2012). It is important because it produces aflatoxin as a secondary metabolite in the seeds of a number of crops both before and after harvest. $A$. 
flavus infections can occur while hosts are still in the field (pre-harvest), but often show no symptoms until post-harvest storage and/or transport. Post-harvest rot typically develops by colonization of the fungus in the seed on storage. In addition to causing pre-harvest and post-harvest infections, many strains produce significant quantities of toxic compounds known as mycotoxins, which, when consumed, are toxic to mammals (Agrios, 2005). Schneider (1987) reported post-production losses in Honduras of 6.5 to 8.7 percent in the field and of 7.4 to 13.9 percent in storage. In this regard, a survey was conducted to know about the incidence, relationship and loss in stored maize due to $S$. zeamais and A. flavus in Chitwan and Surkhet district of Nepal.

\section{MATERIALS AND METHOD}

The study was conducted on Chitwan and Surkhet districts of Narayani and Banke Zone, which lie in the mid-southern and western area of Nepal, respectively, were purposively selected for the study as they are the major maize growing area representing the terai and mid-hills of the country. Purposive selection of Shardanagar VDC of Chitwan and Dasarathpur VDC of Surkhet was done for study as shown in the map of Nepal showing Chitwan and Surkhet districts (Figure 1).

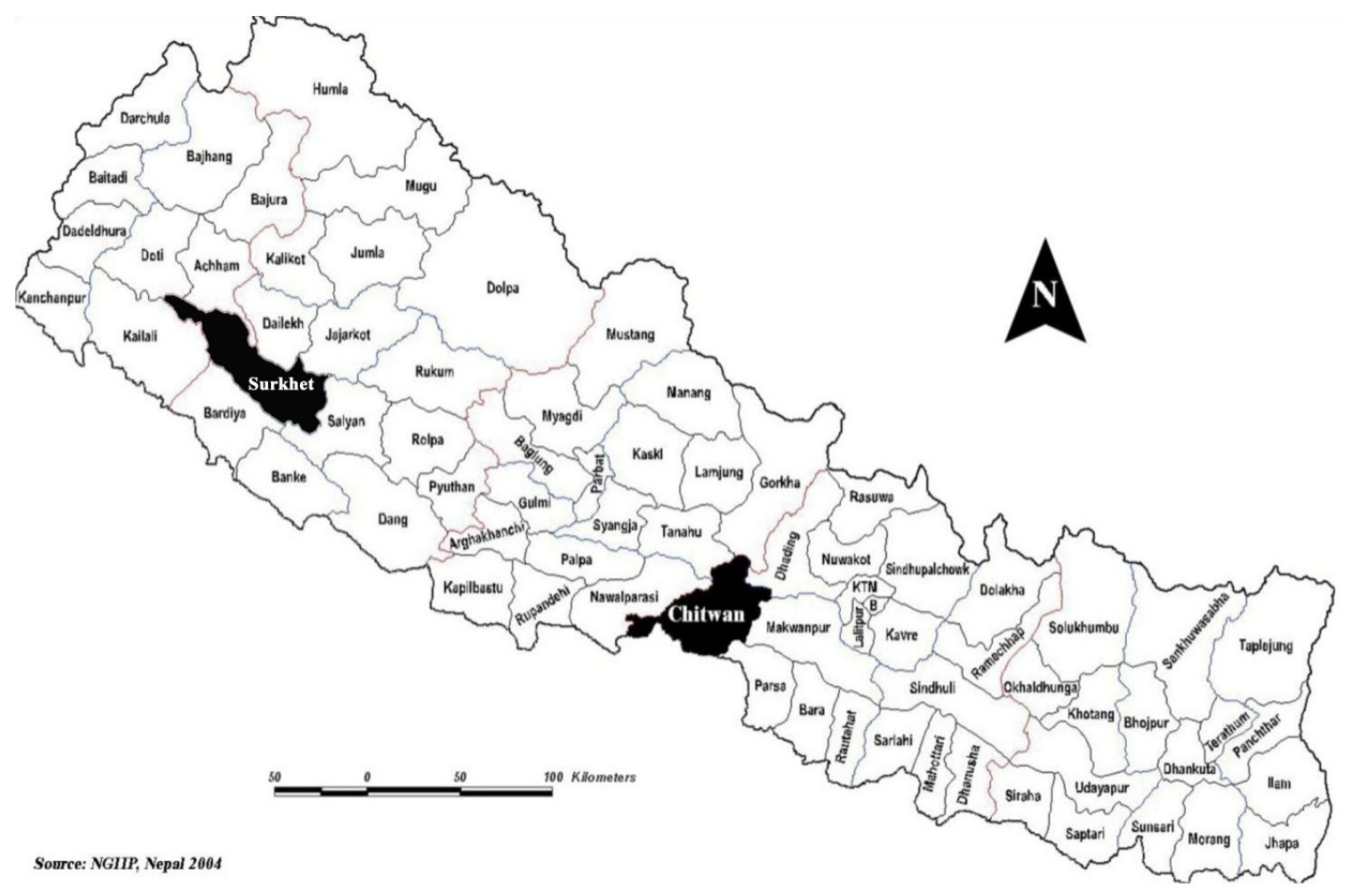

Figure 1: Map of Nepal showing Chitwan and Surkhet districts selected to conduct the survey (Source: NGIIP, Nepal, 2004)

\section{Selection of population and sample}

All the farmers of the proposed study site involved in maize cultivation constituted the study population. Altogether, 120 maize growers, 60 from each district were selected for study by applying simple random sampling technique.

\section{Sources of information and data collection techniques}

Primary data were collected from the survey at the study site and secondary data were collected from published materials from MOAD, DOA, DADO, AEC, NARC, NGOs and INGOs etc. 
The field survey was conducted in April-May 2017 for the collection of primary information. Interview schedule was designed in such a way that it could gather all the information that could address the research objectives. Similarly, key informant survey was carried out to collect the relevant information on maize production. Also face to face interview was carried out with the maize growers for collecting information about disease and pest on storage.

\section{Data analysis}

The primary information obtained from the survey was coded, tabulated and analyzed by using Statistical Package for Social Science (SPSS 20.0), and Microsoft Excel.

\section{RESULT AND DISCUSSION}

\section{Occurrence of Maize weevil and its control measures}

Overall 96.7 percent of HHs reported the occurrence of weevil during storage of maize as shown in table 1. More than 9 in $10 \mathrm{HHs}$ reported occurrence of weevil as storage pests of maize in Surkhet district and all HHs reported occurrence of weevil as storage pests of Maize in Chitwan . Among insect pests, maize weevil (S zeamais) is the most important insects under storage of maize in Nepal (Sherpa et al., 1997; G.C., 2006).

Table 1: Households reporting storage pest of maize under storage, Surkhet \& Chitwan, 2016 $(\mathrm{N}=60)$

\begin{tabular}{cccccccc}
\hline \multirow{2}{*}{ Storage insects } & \multicolumn{6}{c}{ District } \\
\cline { 2 - 8 } & & \multicolumn{2}{c}{ Surkhet } & \multicolumn{2}{c}{ Chitwan } & \multicolumn{2}{c}{ Overall } \\
\cline { 2 - 7 } & Frequency & Percentage & Frequency & Percentage & Frequency & Percentage \\
\hline \multirow{2}{*}{ Weevil } & Present & 56 & 93.3 & 60 & 100 & 116 & 96.7 \\
& Absent & 4 & 6.7 & 0 & 0 & 4 & 3.3 \\
\hline
\end{tabular}

Overall 70.8 percent of HHs used Celphos, 25.8 percent used botanicals (like neem dry leaves, bojho, neem oil etc) and 3.3 percent didn't use any means to control weevil; 73.3 and 68.3 percent of HHs in Surkhet and Chitwan used Celphos to control weevil respectively. Likewise, 20 and 31.7 percent of HHs in Surkhet and Chitwan used botanicals to control weevil in stored maize.

Table 2: Means used to control weevil on stored maize grains, Surkhet \& Chitwan, 2016 $(\mathrm{N}=60)$

\begin{tabular}{cccccccc}
\hline \multirow{2}{*}{ Parameters } & & \multicolumn{5}{c}{ Districts } \\
\cline { 3 - 8 } & & \multicolumn{2}{c}{ Surkhet } & \multicolumn{2}{c}{ Chitwan } & \multicolumn{2}{c}{ Overall } \\
& & Freq. & $\%$ & Freq. & $\%$ & Freq. & $\%$ \\
\hline \multirow{3}{*}{ Means used to control } & Celphos & 44 & 73.3 & 41 & 68.3 & 85 & 70.8 \\
& Botanicals & 12 & 20.0 & 19 & 31.7 & 31 & 25.8 \\
& None & 4 & 6.7 & 0 & 0.0 & 4 & 3.3 \\
\hline Results of methods & Unsatisfactory & 7 & 12.5 & 8 & 13.3 & 15 & 12.9 \\
& Satisfactory & 49 & 87.5 & 52 & 86.7 & 101 & 87.1 \\
\hline
\end{tabular}

Overall, 87.1 percent of HHs reported satisfactory results by using control measures while 12.9 percent reported unsatisfactory. The Chi-square $\left(\chi^{2}=134.52, \mathrm{P}<0.001\right)$ test shows the significant 
relation between the means used and satisfaction of the farmer using the means. The cramer's value (0.749) shows the large relationship exist between the dependent and independent variables.

Similar result for the satisfactory effect of the chemicals against destructive activities of storage pests has been reported to be effective against stored products pests (Adedire et al., 2011). Adedire et al., (2011) reported that the destructive activities of storage pests has beeen subdued by chemical control methods comprising fumigation of stored commodity with carbon disulphide, celphos or dusting with malathion, carbaryl, pirimiphos methyl or permethrin. Similarly in case of botanicals, Gyawali (1993) reported that 50 plant species available in Nepal can be used against insect pests in crops and stored grains. Sweet flag stolen (Acorus calamus), neem (Azadirachta indica) dry leaves, oil, neem seed powder, timur (Zanthoxylum armatum), titepati (Artimesia vulgaris) have been reported to be superior in controlling the maize weevils (Paneru et al., 1996).

\section{Green fungus and its control}

Overall, 97.5 percent of HHs reported appearance of green fungus during storage; 95 percent and 100 percent HHs in Surkhet and Chitwan respectively reported the occurrence of green fungus. Similarly Fandohan et al., (2003) has reported that storage fungi like Fusarium and Aspergillus contributes to loss of more than $50 \%$ of maize grain, and ranks second after insects as the major cause of deterioration and loss of maize. 39.31 percent of HHs reported occurrence of green fungus has been prevented by sun drying and removal of diseased seeds while 60.69 percent of HHs reported occurrence of green fungus but didn't use any means to control the disease. Majority of HHs in Surkhet did not use any means to control the disease (Table 3).

While those HHs applying green fungus control measures reported satisfactory results of applied control measures. The Chi-square $\left(\chi^{2}=120.00, \mathrm{P}<0.001\right)$ test shows the significant relation between the means used and satisfaction of the farmer using the means. The Phi coefficient value (1.00) shows the perfect relationship exist between the dependent and independent variables. Similar result for the control of the fungus by drying the seeds below 13 percent moisture is reported (Stack and Carlson, 2006; Wrather, 2008, Abbas 2005). Moisture content is by far the most important factor affecting the growth of micro-organism in stored maize. After harvest, maize should be sun dried or mechanically dried to 15 percent moisture content within 24 hours. Grain going into long term storage should be dried to 13 percent moisture (Stack and Carlson, 2006; Wrather, 2008; Abbas 2005).

Table 3: Households with green fungus as storage disease and means used for its control, Surkhet \& Chitwan, 2016 (N=60)

\begin{tabular}{cccccccc}
\hline \multirow{2}{*}{ Parameters } & \multicolumn{6}{c}{ Districts } \\
\cline { 3 - 8 } & & \multicolumn{2}{c}{ Surkhet } & \multicolumn{2}{c}{ Chitwan } & \multicolumn{2}{c}{ Overall } \\
\cline { 3 - 8 } & & Freq. & $\%$ & Freq. & $\%$ & Freq. & $\%$ \\
\hline $\begin{array}{c}\text { Occurrence of green } \\
\text { fungus }\end{array}$ & No & 57 & 95 & 60 & 100 & 117 & 97.5 \\
\hline \multirow{2}{*}{$\begin{array}{c}\text { Means used to } \\
\text { control }\end{array}$} & Sun drying and removal of & 9 & 15.7 & 37 & 61.6 & 46 & 39.31 \\
& diseased seeds & & & & & & \\
& No any means used & 48 & 84.2 & 23 & 38.3 & 71 & 60.69 \\
\hline \multirow{2}{*}{ Means used } & Satisfactory & 9 & 100 & 37 & 100 & 46 & 100 \\
& Unsatisfactory & 0 & 0.0 & 0 & 0.0 & 0 & 0.0 \\
\hline
\end{tabular}




\section{Factors favoring incidence of pests in stored maize grains}

Early harvesting and excess moisture in grains during storage seems to be major causes for occurrence of pests during storage in the study site. 9 in $10 \mathrm{HHs}$ reported excess moisture in grain while storage as major cause of incidence of storage pests; 86.7 percent and 98.3 percent of HHs in Sukhet and Chitwan districts respectively reported more moisture in grain while storage as major cause of occurrence storage pest and rest of HHs reported early harvesting as the major factor. The Chi-square $\left(\chi^{2}=123.85, \mathrm{P}<0.001\right)$ test shows the significant relation between factors governing the pest and its occurrence. The Phi coefficient value (1.00) shows the perfect relationship exist between the dependent and independent variables. Brich (1994), reported similar result for the high moisture content over 10 percentage and immature harvest of the crop are the reason for rise in pest occurrence. Increase in moisture leads larvae to tunnel in grains and are responsible for most of the damage. Pupation takes place inside the grain and adults chew their way out through the outer layer of the grain (Mound, 1989).

Table 4: Factors governing incidence of storage pests in maize grains, Surkhet \& Chitwan, $2016(\mathrm{~N}=60)$

\begin{tabular}{ccccccc}
\hline \multirow{2}{*}{$\begin{array}{c}\text { Factors governing } \\
\text { incidence of storage } \\
\text { insects }\end{array}$} & \multicolumn{2}{c}{ Surkhet } & \multicolumn{2}{c}{ Chitwan } & \multicolumn{2}{c}{ Overall } \\
\cline { 2 - 7 } & Frequency & Percentage & Frequency & Percentage & Frequency & Percentage \\
\hline $\begin{array}{c}\text { Early harvesting } \\
\begin{array}{c}\text { More moisture in grain } \\
\text { while storage }\end{array}\end{array}$ & 8 & 13.3 & 1 & 1.7 & 9 & 7.5 \\
\hline
\end{tabular}

\section{Incidence of green fungus at various crop stages}

Overall 59.2 percent of HHs reported incidence of green fungus in ready to harvest cob and 38.3 percent of $\mathrm{HHs}$ reported incidence both in ready to harvest cob and during storage, while only 2.5 percent reported no incidence. During the study, 80 and 38.3 percent HHs in Surkhet and Chitwan districts respectively reported incidence of green fungus in ready to harvest cob while 15 and 61.7 percent HHs reported incidence in both the cases. The Chi-square $\left(\chi^{2}=124.16, \mathrm{P}<0.001\right)$ test shows the significant relation between the green fungus occurrence and various crop stages of infestation. The Cramer's value (0.73) shows the existence of higher relationship between the dependent and independent variables. Campos et al., (2008) reported similar relation for the infestation of $A$. flavus is influenced by many factors and can occur at any stage of food production, from pre-harvest to storage and processing.

Table 5: Households reporting incidence of green fungus at various crop stages, Surkhet \& Chitwan, $2016(\mathrm{~N}=60)$

\begin{tabular}{ccccccc}
\hline \multirow{2}{*}{ Crop stages } & \multicolumn{5}{c}{ Districts } \\
\cline { 2 - 7 } & \multicolumn{2}{c}{ Surkhet } & \multicolumn{2}{c}{ Chitwan } & \multicolumn{2}{c}{ Overall } \\
\cline { 2 - 7 } & Frequency & Percentage & Frequency & Percentage & Frequency & Percentage \\
\hline Harvest ready cob & 48 & 80.0 & 23 & 38.3 & 71 & 59.2 \\
Both (harvest ready and storage) & 9 & 15.0 & 37 & 61.7 & 46 & 38.3 \\
Not-observed & 3 & 5.0 & 0 & 0.0 & 3 & 2.5 \\
\hline
\end{tabular}




\section{Loss of storage grain by green fungus}

Maize production of 1.05 quintal per kattha and 1.35 quintal per kattha was observed in Surkhet and Chitwan districts, respectively; 6.81 and 5.97 percent damage due to green fungus infestation was reported in Surkhet and Chitwan districts respectively; with overall, 6.39 percent loss due to green fungus (Table 6). Similar findings were reported by Schneider (1987) in Honduras about 6.5 to 8.7 percent in the field and of 7.4 to 13.9 percent in storage.

Table 6: Loss of maize due to fungal infestation, Surkhet \& Chitwan, 2016 ( $\mathrm{N}=60)$

\begin{tabular}{lcc}
\hline Districts & Production(Quintal/kattha) & Fungal Damage (\%) \\
\hline Surkhet & 1.05 & 6.81 \\
Chitwan & 1.35 & 5.97 \\
\hline Overall & 1.20 & 6.39 \\
\hline
\end{tabular}

\section{Relationship between weevil infestation and green fungus infestation}

Almost all (90 percent) HHs in Surkhet and all HHs in Chitwan district having weevil infestation reported occurrence of green fungus diseases in storage (Table 8). Results from Chi- Square test indicated significant relation $\left(\chi^{2}=122.10, \mathrm{P}<0.01\right)$ between incidence of weevil infestation and occurrence of green fungus in the study area. The Phi coefficient value (1.00) shows the perfect relationship exist between the dependent and independent variables.

Diener et al. (1987) reported insects physically move conidia adhering to their bodies while feeding and leave them via defecation. Similarly, Dix and All (1987) reported that maize weevil (S. zeamais) is of special interest with respect to the A. flavus infestation problem because it functions as both a pre-harvest and storage insect. He further reported that heat and moisture generated by weevil activity in stored maize grain showed enhanced growth of $A$. flavus.

Table 7: Weevil infestation and green fungus occurrence, Surkhet \& Chitwan, $2016(\mathrm{~N}=60)$

\begin{tabular}{|c|c|c|c|c|c|}
\hline District & & & Imeters & & Frequency \\
\hline \multirow{4}{*}{ Surkhet } & \multirow{4}{*}{ Weevil infestation } & \multirow{2}{*}{ No } & \multirow{2}{*}{$\begin{array}{c}\text { Green fungus } \\
\text { observed }\end{array}$} & No & 1 \\
\hline & & & & Yes & 3 \\
\hline & & \multirow{2}{*}{ Yes } & \multirow{2}{*}{$\begin{array}{c}\text { Green fungus } \\
\text { observed }\end{array}$} & No & 2 \\
\hline & & & & Yes & 54 \\
\hline \multirow{4}{*}{ Chitwan } & \multirow{4}{*}{ Weevil infestation } & \multirow{2}{*}{ No } & \multirow{2}{*}{$\begin{array}{c}\text { Green fungus } \\
\text { observed }\end{array}$} & No & 0 \\
\hline & & & & Yes & 0 \\
\hline & & \multirow{2}{*}{ Yes } & \multirow{2}{*}{$\begin{array}{c}\text { Green fungus } \\
\text { observed }\end{array}$} & No & 0 \\
\hline & & & & Yes & 60 \\
\hline
\end{tabular}

\section{CONCLUSION}

Field survey in Shardanagar VDC of Chitwan and Dasarathpur VDC of Surkhet revealed $S$. zeamais and A. flavus were the major pest in all most all HHs during the maize storage. Most of the (93.3\%) HHs in Dasarathpur and all (100 \%) HHs in Shardanagar VDCs reported weevil infestation and $95 \%$ and $100 \%$ HHs in Dasarathpur and Shardanagar VDC reported A. flavus infestation in storage. $73.3 \%$ used Celphos tablet followed by botanicals (20\%) to control the storage pest. Similarly $15.7 \%$ of the farmers apply sun drying and removal of the $A$. falvus infested seed while remaining $84.3 \%$ of the farmers use no any measures due to the busy agricultural schedule. The lack of knowledge 
about the moisture maintenance is a main factor against the high infestation of the pest and disease in storage. Results from Chi- Square test indicated significant relation $\left(\chi^{2}=122.10, \mathrm{P}<0.01\right)$ between incidence of weevil infestation and occurrence of green fungus in the study area. The Phi coefficient value (1.00) shows the perfect relationship exist between weevil and green fungus occurrence in the study areas. The overall annual damage by the A. flavus was $6.39 \% .90$ percent HHs in Surkhet and all HHs in Chitwan district having weevil infestation reported occurrence of A. flavus in storage. Therefore, maize weevil as major insect while $A$. flavus as major disease of maize grains on storage was recorded on all most all HHs in the study areas. And their relationship was highly significant which indicates their positive relationship, i.e. the weevil plays an essential role in growth and spread of fungus.

\section{REFERENCES CITED}

Abbas, K. H. (2005). Aflatoxins and food safety. (T. a. Group, Ed.) New York, USA: CRC Press.

Adedire, C.O., Obembe, O.O., Akinkurolele, R.O., \& Oduleye, O. (2011). Response of Callosobrunchus maculatus (Coleoptera: Chrysomelidae: Bruchinae) to extrats of cashew kernels. Journal of Plant Disease and Protection, 118(2), 75-79.

Agrios, G. N. (2005). Plant Pathology (5th ed.). Cambridge, United States: Elsevier Academic Press.

Birch, L. C. (1944). Two strains of Calandra oryzae L. (Coleoptera). Australian Journal of Experimental Bilogy and Medical Science, 22, 271-275.

Campos, S. G., Cavaglieri, L. R., Fernandez, M. G., Dalcero, A. M., Kruger, C., \& Keller, L. A. (2008). Mycobiota and aflatoxins in raw materials and pet food in Brazil. Journal of Animal Physiology and Animala Nutrition, 92(3), 377-383.

Diener, U. I., Cole, R. J., Sanders, T. H., Payne, G. A., Lee, S. L., \& Klich, M. L. (1987). Epidemiology of aflatoxin formation by Aspergillus flavus. Annual review of Phytopathology, 25, 249-270.

Dix, D. E., \& All, J. N. (1987). Interactions between maize weevil (Coleoptera: Curculionidae) infestations and infection by Aspergillus flavus and other fungi in corn. Journal of Entomological Science, 22, 108-118.

Fandohan, P., Hell, K., Narasas, W. O., \& Wingfield, M. J. (2003). Infection of maize by Fusarium species and contamination with fumonisin in Africa. African Journal Of Biotechnology, 2(15), $570-579$.

FAO. (2013). World food and agriculture. Rome: Food and Agriculture Organization of United States.

GC, Y. D. (2006). Efficacy of indegenous plant materials and modified storage structures to insects pests of maize seed during on farm storage. Journal of Institute of Agriculture and Animal Science, 27, 69-76.

Gyawali, B. K. (1993). Integrated pest management through indigenious techniques in Nepal. Kathmandu, Nepal: Winrock International.

Masayuki, M., \& Katsuyai, G. (2010). Aspergillus: Molecular bilolgy and genomics. Newyork, USA: Horizon Scientific Press.

Megan, N., Hope, R., Cairns, V., \& Aldred, D. (2003). Postharvest fungal ecology: Impact of fungal growth and myco-toxin accumulation in stored grain. European Journal of Plant Pathology, 109, 723-730.

MoAD. (2014/15). Statistical information on Nepalese Agriculture. Singh Darbar, Kathmandu, Nepal: Agribusiness Promotion and Statistics Division. 
Mound, L. (1989). Common insect pests of stored food products (7th ed.). London: British Museum (Natural History).

Paneru, R. B., Khanal, V. R., \& Bhandari, M. R. (1996). Testing of the efficacy of some materials against weevil in stored maize. Dhankuta: Pakhribas Agriculture Center.

Ramirez-Camejo, L. A., Zuluaga-Montero, A., Lazaro-Escudero, M. A., Hernandez-Kendall, V. N., \& Bayman, P. (2012). Phylogeography of the cosmopolitan fungus Aspergillus flavus. Journal of Fungal Biology, 116(3), 452-463.

Schneider, K. (1987). Project Experience for the reduction of post-harvest losses in Honduras. Honduras: Ministry of Natural Resources.

Sherpa, L., Ojha, N. G., \& Sharma, A. R. (1997). Why farmers adopt or reject Agricultural Technology: A case study of improved maize and wheat varieties in the Ex-local largest area of Pakhribas Agriculture Center at Dhankuta. Nepal: Pakhribas Agriculture Center.

Singh, C. (2002). Modern techniques of raising field crops. New Delhi, India: Oxford and IBH Publishing Co. Pvt. Ltd.

Stack, J., \& Carlson, M. (2006). Aspergillus flavus and Aflatoxins in Corn. University of Nebraska Lincoln Extension (Vol. 402). Lincoln: Devision of the Institute of Agriculture and Natural Resources.

Wrather, J. A. (2008). Aflatoxin in Corn. Missouri, USA: University of Missouri Delta Center. 